v. 7, n.1

Vitória-ES, Jan - Apr.2010

p. 111-133 ISSN 1808-2386 DOI: http://dx.doi.org/10.15728/bbr.2010.7.1.6

\title{
Operational and financial performance and market concentration under the focus of paradigm structure-behavior-performance: an exploratory study in the Brazilian dairy industry in the period 1997 to 2006
}

\author{
Esmael Almeida Machado ${ }^{\dagger}$ \\ Mato Grosso do Sul State University \\ Lauro Brito de Almeida ${ }^{\square}$ \\ Paraná Federal University \\ Paulo Mello Garcias ${ }^{\mathbf{x}}$ \\ Paraná Federal University Alencar \\ Garcia Bacarji ${ }^{\Psi}$
}

Federal Institute of Education, Science and Technology of Mato Grosso

\begin{abstract}
Recent studies indicate that the expected process of market concentration in the dairy industry in the country was not confirmed after the deregulation that has take place since early 90s. In this scenario, considering the paradigm of Structure-Behavior-Performance (ECD), the research issue guiding this study is: Did the operating and financial performance of dairy companies in Brazil between 1997 and 2006 influence the levels of concentration in the sector? The indicators of operational and financial performance were calculated based on Fleuriet's model (1978) and the analysis of market structure by means of the indicator of the estimate of the concentration ratio - CR $(k)$ - of the sector for the period. The study is descriptive and the sample is intended, given the unavailability of financial statements for all companies in the period under analysis. The results of the investigation suggest that the performance of the companies, as per their operational and financial indicators, lead to changes in market structure and in the position of the companies measured by the concentration ratio $\mathrm{CR}(k)$.
\end{abstract}

Key words: Structure-behavior-performance, Fleuriet's Model, dairy industry

Received in 09/05/2008; accept in 04/14/2010 Corresponding authors*:

\begin{tabular}{|c|c|c|}
\hline & 口 & $\mathbf{p}$ \\
\hline Master's in Accounting from & Ph.D. in Control and & Ph.D. in Economics from the \\
\hline Paraná Federal University (UFPR) & Accounting of the University of & School of Economics, \\
\hline Assistant Professor at Mato & São Paulo (FEA/USP) & Administration and Accounting of \\
\hline Grosso do Sul State University & Assistant Professor at Paraná & the University of São Paulo \\
\hline (UEMS) & ederal University (U & (FEA/USP) \\
\hline Address: Cidade Universitária de & Address: Av. Prefeito Lothário & Assistant Professor at Paraná Federal \\
\hline Dourados - Caixa Postal 351, & Meissner, 3400 - Sala 17 - & ity (UFPR) Address: Av. \\
\hline Dourados - MS - Brazil & Campus III - Jardim Botânico, & Prefeito Lothário \\
\hline CEP: 79804-970 & Curitiba _ PR _ Brazil & Meissner, 3400 - Sala 17 - Campus \\
\hline E-mail: esmael@usp.br & -1 & III - Jardim Botânico, Curitiba - PR \\
\hline Telephone: (67) 99136582 Fax: & E-mail: gbrito@uol.com.br & - Brazil. \\
\hline (67) 39266331 & & CEP $80210-170$ \\
\hline & (41) 33604404 & $\begin{array}{l}\text { E-mail: paulomg@ufpr.br } \\
\text { Telephone: (41) } 33604404 \text { Fax: } \\
\text { (41) } 33604404\end{array}$ \\
\hline
\end{tabular}

$\Psi$

Master's in Agribusiness from the Department of Economics and Administration of Mato Grosso do Sul Federal University (UFMS). Professor at the Federal Institute of Education, Science and Technology of Mato Grosso Address: Juliano Costa Marques, s/n Bela Vista, Cuiaba, MT Brazil - CEP 78000-000 E-mail: alencarbacarji@gmail.com Telephone: (065) 36539206 Fax: (065) 36539206

Editor's note: This paper was accepted by Antonio Lopo Martinez 


\section{INTRODUCTION}

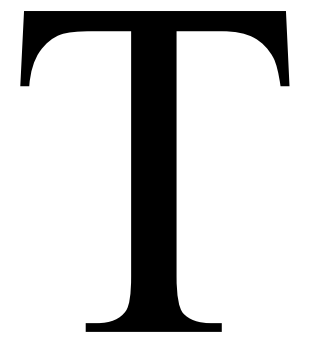

he 90's were characterized by a deep change in he structural conjuncture of the Brazilian economy, fostering marked changes in the Brazilian industrial complex. Such changes, resulting from the commercial opening, have established new forms of performance of the agents, especially in agricultural industries (CUNHA, 2005).

In the framework of the changes held in the structural conjuncture of Brazilian economy, there occurred changes in the institutional environment of productive chains. In the productive chain of milk, in particular, the changes held, aligned to the changes in the structural conjuncture of the Brazilian economy, held at the time, highlighting the clearing of prices in all links of the productive chain, commercial opening (allowing the importation of dairy products), the implementation of Mercosul, among others (JANK et. al. (1999).

Such changes redefined the competition patterns, putting in checkmate milk producers and dairy companies. In the industrial chain, it is possible to note the progress of private companies, especially the transnational ones, toward acquisition or incorporation of Brazilian private companies and cooperatives, in detriment to the cooperatives of milk producers, which historically were very important receiving and supplying the pasteurized milk market (FIGUEIRA and BELIK, 1999).

As a result of the structural changes occurred in the period and the process of modernization of the dairy industries, the productive units became specialized and, consequently, oriented their production to the domestic and/or foreign market. This way, in the course of the 90's and beginning of the years 2000, the process of specialization of production is seen as an strategy in obtaining productivity gains allied to cost reduction aimed at ensuring competitive advances to the agents involved in this productive chain.

The reconfiguration of the competitive environment occurred as of the changes in institutional environment promoted a concentration of few dairy industries prevailing over high portions of the consumers' market. It is added to this scenario the increase in productivity gains of milk by milked cows and the increase of demand in the Brazilian market. These factors, together, influence the performance of the industry in the sector, in a competitive environment and one with higher efficiency in milk 
production. In this scenario, the growing demand leads the need for new investments, whether to expand industrialization capacity, or to modernize the industrial parks and processes, aiming at efficiency and reduction of costs (PONCHIO et. al., 2005).

The performance of the dairy industry in terms of market share on the receipt of milk keeps close relationship with the physical volume of sales and their financial equivalent billing. Therefore, in this context, billings of dairy companies are directly impacted by the physical quantity of milk received.

For Filho \& Matte (2006) in a scenario of market concentration of the dairy industry in Brazil, the stabilization of the national economy and the deregulation of prices in the dairy sector are factors that affect the dairy industry and it's restructuring. The authors concluded that between 1990 and 2000 the rate of concentration of the four largest companies in the market showed relative stability, showing that in this group the expected process of concentration had not occurred.

The research consulted (PONCHIO et. al., 2005; CUNHA, 2005; FILHO \& MATTE, 2006) does not investigate if the reflection of the performance of the dairy industry influence market concentration levels, considering the paradigm of StructureBehavior-Performance (ECD). Thus, this study is guided by the following research question: Did the operational and financial performance of dairy companies in Brazil between 1997 and 2006 influence the levels of concentration in the sector? Therefore, the general objective is to identify if the operational and financial performance of dairy companies has influenced the concentration levels in the sector in the period 1997 to 2006.

This research is justified by the fact that it broadens the range of approaches to studies of market concentration under the paradigm of Structure-BehaviorPerformance (ECD), and also because it (i) addresses whether the operational and financial performance of dairies influences market concentration levels and (ii) uses the operational and financial indicators proposed in Fleuriet's model (1978) as proxy in the performance of the companies under investigation.

Besides this introduction, the text consists of the following parts: (i) in the second section, we present aspects of the situation of the dairy sector as of the nineties, the conceptual foundations of the paradigm ECD and the Fleuriet's model (1978), 
basis for calculation of the economical \& financial performance indicators; (ii) in the third section, we address the methodological aspects of the research as to sample, collection and treatment of data; (iii) the results and discussion are the subject of the fourth section, and (iv) in the fifth section, final considerations, our thoughts on the research.

\section{SCENARIO OF THE DAIRY SECTOR AFTER 1990. CONCEPTUAL FOUNDATIONS OF STRUCTURE-BEHAVIOR-PERFORMANCE. OPERATIONAL AND FINANCIAL PERFORMANCE UNDER THE VIEW OF FLEURIET'S MODEL}

\subsection{Scenario of the dairy sector after 1990}

The Brazilian economy has undergone profound changes since early nineties, including the adoption of liberal economic policies, which were inducing to development, implementation and institutionalization of a new competitive environment, resulting in a reorganization of the industrial sector.

The dairy industry, which, in 1999, accounted for about $15 \%$ of billings in the food industry, was one of the most affected (Filho and Matte, 2006). Research carried out before the end of the 90's (JANK and GALAN, 1998; GOMES, 2001; BRANDÃO, 1999) already portrayed the causes and consequences of such changes, shown by significant changes in all links of the dairy productive chain, signaling how differing and competitive the environment would be in the next few years.

The changes experienced by the Brazilian economy (resulting mainly from increased flows of foreign capital) have also established new forms of performance of the agents of the dairy productive chain - changes observed in the scope of competition - which brought about intense equity change in the structure of this industry (CARVALHO, 2005).

In the dairy industry, the changes occurred can be credited by the deregulation of the market in a sector, up to that time marked by technological delay in previous periods and market structure with strong governmental intervention.

Other events contribute to the occurrence of changes in the dairy industry, such as some identified during the process of industrial transformation, especially regarding the international market for dairy products. The need to compete with a tendency 
toward valorization in the quality of dairy products has resulted in the practice of differential payment for better quality milk, taking as parameters the content of protein, fat and somatic cell count, have signaled the behavior of large dairy companies (COSTA et al., 2004).

In the period before the changes occurred in the Brazilian economy, Jank et. al. (1999) found that companies that are members of the dairy industry were divided into: multinational corporations, national groups of companies, dealers without factory, dairy cooperatives and small dairy firms, and each of these groups with their specificities, formed the industrial complex of the Brazilian dairy chain. After the changes in Brazilian economy, deep structural changes in the Brazilian dairy industry were noted. These changes began in the nineties, with the development of an entirely new competitive environment that resulted from market deregulation, commercial opening to foreign trade and Mercosul and the process of stabilization of the economy.

Related to this aspect of deregulation, according to Santos and Vilela (2000), for over forty-five years (approximately from 1945 to 1991) the government set the price (nominal) of the milk to the producer, consumer and the profitability margins of each one of the links in the productive chain.

During this period, resulting from regulatory lack of incentives, there was stagnation of the segments in the supply chain. Technological advances in the period were episodic and restricted to those properties that supplied the markets with pasteurized milk types A and B. The range of products offered to consumers remained almost unchanged during these four decades. The end of the regulation in 1991 coincided with the advancement of the process of trade liberalization.

\subsection{Conceptual foundations of the Structure-Behavior-Performance}

The terms of Industrial Economics (from French) and Industrial Organization (from English) are used in Brazil to describe the Industrial Economics discipline. As an area of knowledge, it thrived as of 50's directed toward the development of new study methods of the operation of various sectors of industry.

The purpose is to understand more broadly the real dynamics of the various industrial sectors and, consequently, the way companies, markets, institutions and processes relate (KUPFER \& HASENCLEVER, 2002; KON, 1999). 
Kon (1999) argues that the theoretical foundations to analyze the Industrial Economics nowadays are contained partly in the context of microeconomics, because they cover activities of individual economical units of decision-making. However, its amplitude and the entire field of economic theory have evolved throughout the years, technology, and essentially by ideologies prevailing in each period of history.

From this perspective, the magnitude of the technologies and ways of organizing industrial and agro industrial production changes since the mid-twentieth century have assured Industrial Economics and the issues related to it prominent attention in contemporary economic analysis. Therefore, costs, innovation, pricing, business growth, competitiveness, market structure and concentration, today, are subjects of growing interest in the Brazilian economy.

The study of market structure and concentration is referenced on the theoretical principles of the Theory of Industrial Organization and this study has focus on paradigm Structure-Behavior-Performance (ECD). The analysis conducted by Moraes (1996) on agro-industrial markets, for example, found that the performance of an industry is dependent on the behavior and this, in turn, on the structure, as prescribed by Carlton and Perloff (1994) and Sherer and Ross (1990).

In the ECD model, the basic assumption is that the structure of a sector or industry determines the behavior of the companies and, therefore, their performance. This model has been used in the analysis of the sector regulation and dynamics of technological innovations (KUPFER and HASENCLEVER, 2002). By design, in the ECD ratio, there is a unidirectional dependence on these variables and, therefore, the performance of an industry depends on the behavior, and this depends on the structure.

Included in the performance variable are product quality, technical progress, productive and allocating efficiency and profits. Included in behavior are connected factors such as pricing practices, investments and advertising strategy that buyers and sellers use. Structure involves factors like the amount of sellers and buyers in the sector, barriers to market entry, vertical integration level between raw material production and distribution of the final product at retail, the location and geographic concentration of link chains, among others.

These variables are influenced by demand conditions, supply and government policy, as, for example, price elasticity, seasonality, growth rate of demand and BBR, Braz. Bus. Rev. (Engl. ed., Online), 
availability of substitute goods, some of the demand conditions that interfere in structure and behavior, while technology, product durability, location and ownership of raw-material are factors related to offer. In turn, governmental policies can affect structure and behavior of the industry through laws, incentives and regulations (SHERER and ROSS, 1990).

The development of the ECD model has led, however, to a new aspect, which supports the endogeneity among the variables of the structure (DONSIMONI et al. 1984). Participating in this scenario, Rocha, Bueno and Pires (2004), who provide evidence on this approach on the research findings on the Dynamics of Market Concentration in the Brazilian Industry, between periods 1996 and 2003.

The discussion on endogeneity among structure variables took place on two fronts. On the empirical side, there are two kinds of evidence that question the linearity of the ECD argument: (a) the inability of the basic conditions to explain the concentration in a unidirectional way, although they are correlated. This happens when the level of market concentration is correlated with the level of economies of scale in terms of factory unit and firm; yet, the level of minimum scale is below the level of concentration reached in most markets, and (b) the poor performance of the concentration as an explanatory element of performance variables (SCHMALENSEE, 1989).

In this regard, Rocha, Bueno Pires and Pires (2004) argue that "[...] the concentration appears as a result of a growth process and not as determining factor " Further and thorough analyses may show the behavior of firms within the market, where smaller companies are predominant when they enter and are more likely to exit.

The discussion on the ECD paradigm is highlighted in this research in assessing the concentration in the dairy industry. Carlton and Perloff (1994), regarding the determination of indicators to assess market concentration, highlight two important reasons to address the issue.

First, they argue that the determination provides for a comparative analysis of concentration among different industries. Secondly, the determination enables conditions for definitions in the scope of economic policy, since it provides subsidies for the actions of regulators in market intervention aimed at preventing changes in the 
concentration of any given industry specifying, preventively, general measures to manage conflict among the companies or, further, to regulate imminent mergers.

In addition, concentration measures help in market structure evaluation, allowing identifying the dominant behavior of economic agents. In short, their usefulness is in identifying sectors for which market power is significant. In the same line of argument, Schmidt and Lee (2002) suggest that estimates of concentration indicators are linked to knowledge of market structure and competition.

Therefore, when evaluating the market from this angle, the concentration indices have an important role, especially if the process is coupled with performance measures adequately observed.

\subsection{Operational and financial performance under the view of Fleuriet's model}

Michel Fleuriet, late in the 1970s, after conducting research with a focus on analysis of budget and financial planning in Brazilian companies, proposed a model to analyze the working capital as of variables extracted from the balance sheet. This model assesses the operational and financial capacity of entities, analyzing the working capital, treasury and the need for working capital.

The working capital (CDG) represents the long-term debt used in current assets. The long-term debt is represented by its own resources, equity, and resources of third parties due in the long term. Thus, the long-term funds not invested in permanent investments and long-term receivables are used to fund operating activities.

The cash balance (T) is defined as the difference between financial assets and financial liabilities. T, when positive, indicates the existence of short-term funds, ensuring the company's solvency margin and increasing its financial security. When negative, it indicates the existence of financial difficulties, that is, short-term financial resources used to finance operating activities and even long-term and permanent investments.

The need for working capital (NCG) is the permanent application of funds to finance operational activities and is due to the arrhythmia of inputs and outputs of operational flows. It is represented by the difference between current operational assets and liabilities. When the balance of NCG is positive it means that the operational investments are funded or by the CDG, when positive, or by financial current liabilities 
when CDG is negative. This occurs when the sources of operational resources are insufficient to finance operational investments. In contrast, when NCG is negative, it means that the company is able to have sources of operational resources, besides the need to invest in operational activities.

The dynamic analysis model of working capital presented by Fleuriet (1978), deals with the interaction and relationship among model elements, i.e., the policies adopted at tactical (T), operational (NCG) and strategic (CDG) level influence and provide changes in the financial structure of the company and, hence, the operational and financial performance. Thus, from Fleuriet's model, it is possible to evaluate the performance of an enterprise and provide information for the determination of the future trends of a business or even an activity sector, with fewer risks. Braga (1991) conducted a study in which he applied Fleuriet's model to a company and compared the results with the indicators obtained by traditional analysis.

The author concluded that Fleuriet's model provides more thorough and organized explanations on the operational and financial performance of the company, when compared with the indicators obtained by traditional analysis. In addition to internal use by managers, Fleuriet's model enables projections on the operational and financial situation of the company by external users, such as stakeholders, market analysts, creditors, potential investors and others.

\section{METHODOLOGY}

\subsection{Research characterization}

This study is characterized as a descriptive research, seeking to establish the relationship among variables (GIL, 1999). In addition to describing the characteristics of a given sample, in the case companies from the dairy sector, within a specific temporal horizon, it has the objective to identify if the operational and financial performance of the companies influences the concentration levels of the sector under paradigm ECD.

\subsection{Population, sample and data collection}

The population under investigation constitutes companies active in the dairy industry and is included in the database of the Empresa Brasileira de Pesquisa Agropecuária (EMBRAPA), the National Council of Agriculture (CNA), the Brazilian 
Confederation of Dairy Cooperatives (CBCL) and the Brazilian Institute of Geography and Statistics (IBGE).

Once the outline is defined, the criterion of intended selection of the sample was by means of the preparation of a ranking consisting of 15 companies. The temporal horizon of analysis of the dairy companies comprising the ranking covers the period from 1997 to 2006.

The classification was made based on the amount of milk received in 2006 . The companies making up the ranking were responsible for receiving $42 \%$ of the milk destined for the industry in 2006.

Data relative to milk receiving and production were collected from EMBRAPA, CNA, CBCL and IBGE. As a complement, accounting statements were collected from the companies included in the ranking by reception of milk. The collection sources were magazine Exame, Maiores e Melhores Edition, year 2007 and the database of Economática.

\subsection{Treatment of data}

To measure the market concentration, we used the concentration ratio of $k$ order, which, according to Resende \& Boff (2002, p. 77) in Kupfer \& Hasenclever (2002), “(...) is a positive index that provides the portion of market of the largest $k$ companies of the industry $(k=1,2, \ldots, n)$. So,

$$
\begin{aligned}
& \mathrm{kR}(k)=\sum s_{i} \\
& \mathrm{i}=1
\end{aligned}
$$

The authors claim:

$$
\begin{aligned}
& \text { The highest the value of the index, the higher is the market power exercised } \\
& \text { by the largest } k \text { companies. In the empirical applications, one usually take } \\
& \mathrm{k}=4 \text { or } \mathrm{k}=8 \text {, that is, one considers only the participation of the four or eight } \\
& \text { largest companies. The respective concentration ratios are known CR(4) } \\
& \text { and CR(8). }
\end{aligned}
$$

In determining $\mathrm{CR}(k)$, it was considered the total liters of milk received from the producers at national level. By definition, $\operatorname{CR}(k)$ is the portion of the market of a given number of companies $(k)$. The values of $\mathrm{CR}(k)$ can be expressed in the percentage or decimal form and represent the portions of market attributed to the largest companies. 
Variable $s_{i}\left(s_{i}=\mathrm{X}_{\mathrm{i}} / \mathrm{X}\right)$ represents the portion of the market of each company under analysis (RESENDE \& BOFF, 2002, p. 77 in KUPFER \& HASENCLEVER, 2002), whereas $X$, the volume of milk processed by the company "i" and $X$ the total volume. We chose to work with the concentration ratios for levels $\mathrm{CR}(4), \mathrm{CR}(8)$ and $\mathrm{CR}(15)$. For the analysis of operational and financial performance, the indicators were calculated based on the model of dynamic analysis of working capital of Fleuriet (1978).

\section{RESULTS AND DISCUSSION}

\subsection{Evolution of production and reception of milk}

The deregulation of the dairy sector in Brazil has definitely contributed to a significant increase in milk production, presenting an average rate of growth of $3.4 \%$ per year - accrued to $71.4 \%$ - for the period between 1990 and 2006. In the same period, the volume of milk received by the dairy industries increased $73.4 \%$ taking as a basis the year of 1990. There is a lack of rhythm between total milk production and total milk received, whose difference is $2 \%$.

Ponchio et. al. (2005, p. 4) highlight that between years 1990 and 2002 there was a variation of $-1.06 \%$ in the amount of milked cows and, on the other hand, a geometric growth rate [TGC] of $3.30 \%$ for total milk production and $4.41 \%$ for the productivity by liters/cow/year. For the authors, the reduction in the volume of milk imported by Brazil between 1996 and 2004 indicated a dropping tendency for the following years. In relative terms, in 1996 Brazil imported the equivalent to $12 \%$ of national production, while in 2004, the volume of imported milk started to represent $1.5 \%$ of Brazilian production.

However, in spite of the productivity of milk production in natura, the price paid by dairy companies to the producer varied negatively between 1990 and 2003, recording a real drop of 59.05\%. In terms of comparison, according to the Brazilian Institute of Geography and Statistics (IBGE), the Consumer's Price Index (IPCA) for milk and derivatives, considering only the post-Real period, presented a positive variation of $25 \%$ up to 2004 (Ponchio et. al., 2005, p. 6).

Ponchio et. al. (2005, p. 10) prepared an estimate for a 10-year period (20052015) relative to the volume of milk produced in Brazil and consumption per 
capita of the product. Based on the estimate, a surplus of the product was estimated as of 2006 and a scenario was suggested with increase in the exportation or consumption per capita.

In this scenario, the modernization of the industrial park of the sector would become an inevitable alternative to supply the need for industrialization of the growing milk offer. Table 1, as of information available in the Balance Sheet of the companies for 2005 and 2006, shows a variation of $47 \%$ and $32 \%$ of investments in the fixed assets of 5 (five) industries considered as one of the 15 (fifteen) largest recipients of milk in Brazil in 2006.

Table 1 - Investment in the Fixed Assets of the Dairy Industry: 2005 and 2006

\begin{tabular}{l|l|l|l|l|l|l}
\hline \multicolumn{7}{|c}{ Variation $\%$} \\
\hline Year & ITAMBÉ & EMBARÉ & CONFEPAR & BATÁVIA & VIGOR & Average \\
\hline 2005 & 95,2 & 33,6 & 84,7 & 12 & 8,7 & 47 \\
\hline 2006 & 15,6 & 7,6 & ND & 97,6 & 7,7 & 32 \\
\hline
\end{tabular}

Source: Maiores e Melhores Empresas Brasileiras (2008)

The increases in investments in fixed assets, as per Table 1, are adherent to the projections of the authors, indicating an expansion of fixed assets, which, by the nature of the group under consideration, is characterized by machines and production equipment.

\subsection{Concentration Ratio CR $(k)$}

The companies included in Table 1 integrate the ranking prepared by the milk receiving criterion are the largest in the dairy industry, occupying the $2 \mathrm{nd}$, 7 th, 8 th, 10th and 15th positions, respectively.

The classification of the fifteen companies is presented in Annex I and is arranged according to the volume of milk received in 2006. Based on the data included in Annex I, one can infer that from the total milk production in Brazil in 2006, 42\% were received by the 15 (fifteen) largest companies in the sector.

The company Vigor, $15^{\text {th }}$ in the ranking, received the equivalent to $1.5 \%$ of national milk production in 2006; therefore, it is possible to ascertain beyond doubt that $58 \%$ of total production has the reception pulverized among the other active agents in the sector. 
The market indicators were estimated based on the classification by volume of milk received as a result of data availability.

It is worth highlighting that other investigations (FILHO and MATTE, 2006; CUNHA, 2005; PONCHIO et. al., 2005) used the same criterion to classify the largest companies in the sector and to estimate market indicators.

The estimate of market indicators is shown in Table 2, presenting $\mathrm{CR}(k)$ at three levels. The first level considers the 4 (four) largest companies in the dairy industry; the second level the 8 (eight) largest companies, both calculated from 1996 up to 2006 and, lastly, the third level the 15 (fifteen) largest companies, calculated as of 2001 .

The calculation of the market share for $\operatorname{CR}(k)$ considered the participation of each company in relation to total milk received in Brazil. In both cases, there is reduction in the participation of the largest industries between 1997 and 2006, indicating reduction in the level of concentration of the sector.

Table 2 - Level of concentration of market (CRK): 1997 a 2006

\begin{tabular}{c|r|c|c|c|c|c}
\hline ANO & Recepção & CR4 $(\%)$ & Recepção & CR8 $(\%)$ & Recepção & CR15 $(\%)$ \\
\hline 1997 & 3.673 .010 & 34,36 & 5.015 .882 & 46,93 & & \\
\hline 1998 & 3.550 .261 & 32,29 & 4.859 .056 & 44,55 & & \\
\hline 1999 & 3.565 .794 & 32,01 & 4.632 .123 & 42,23 & & \\
\hline 2000 & 3.845 .722 & 31,76 & 4.991 .023 & 41,85 & & \\
\hline 2001 & 3.981 .259 & 30,13 & 5.152 .279 & 39,08 & 6.431 .595 & 49,42 \\
\hline 2002 & 3.880 .196 & 29,35 & 4.740 .251 & 36,80 & 6.043 .229 & 45,71 \\
\hline 2003 & 3.761 .959 & 27,61 & 4.681 .988 & 35,22 & 6.065 .931 & 44,51 \\
\hline 2004 & 3.462 .962 & 23,89 & 4.408 .454 & 31,54 & 5.936 .485 & 40,43 \\
\hline 2005 & 4.146 .396 & 25,46 & 5.119 .402 & 33,04 & 6.928 .433 & 42,02 \\
\hline 2006 & 4.251 .035 & 25,51 & 5.208 .407 & 33,02 & 7.056 .598 & 42,35 \\
\hline
\end{tabular}

Source: Data organized by the authors based on research

It is clear there is a tendency toward lack of concentration of the sector up to 2004 among the three $\mathrm{CR}(k)$ discussed (CHART 1), period that marks the beginning of the inversion of the concentration ratio. Notably, in spite of the perceptible reduction in the level of concentration measured by $\mathrm{CR}(k)$, it is not possible to verify an expansion or significant alteration among the largest companies in the sector. 


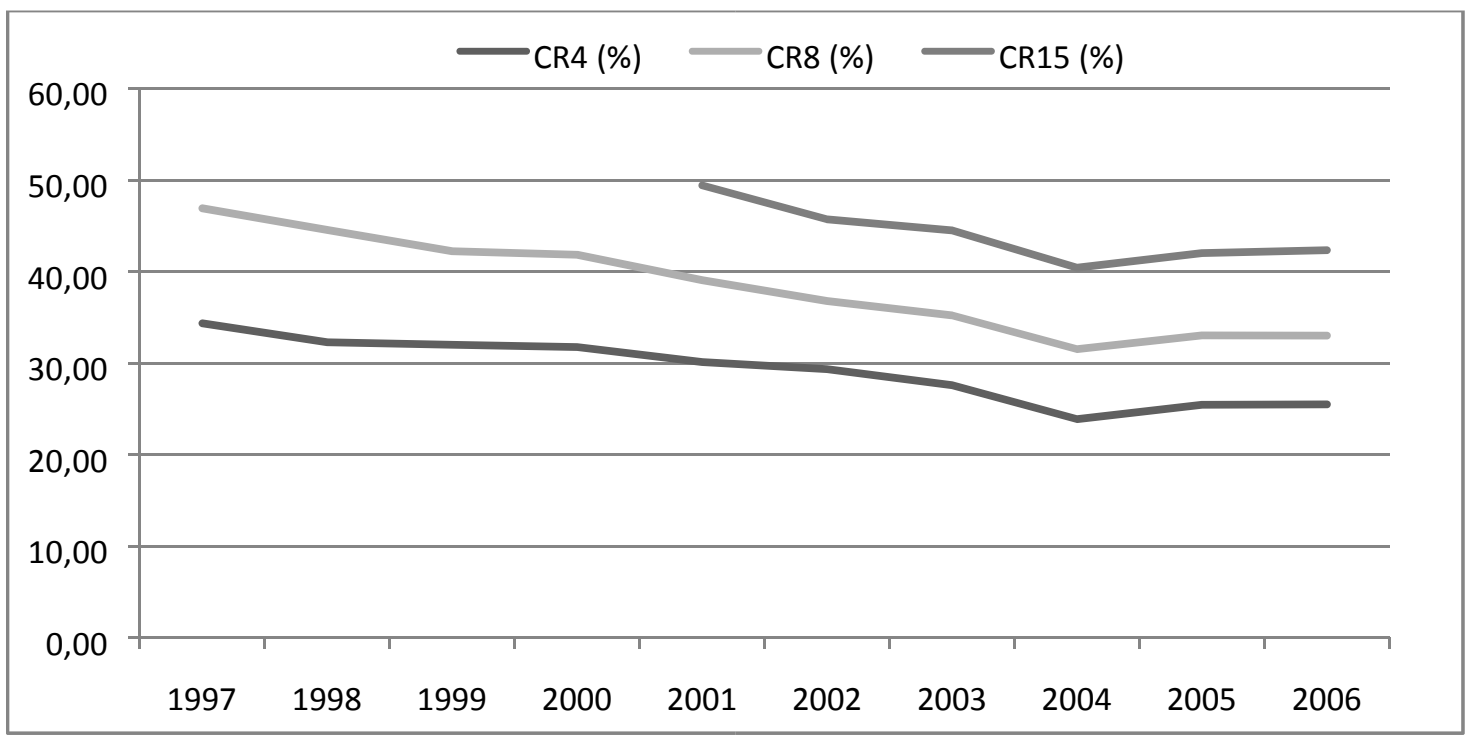

GRÁPH 1 - LEVEL OF CONCENTRATION OF MARKET (CRK): 1997 A 2006

Source: Data organized by the authors based on research

Initially, one must emphasize the influence of $\mathrm{CR}(4)$ in the other levels of analysis, since, this measures covers the four largest companies of the sector. For a full analysis of Chart 1, one must observe Annex I at the same time. This way, it is possible to note that the drop of Parmalat in the ranking of reception of milk coincides with an expansion of the market participation of the other companies making up CR(4) reflecting an increase in the concentration of the sector. Finally, as of 2004, the sector resumes a tendency of concentration, basically because Nestlé, Itambé and Elege expanded milk reception as of a decrease in the portion of the market of Parmalat.

\subsection{Operational and financial performance under the view of the fleuriet model}

The analysis of operational and financial performance, based on Fleuriet's model (1978) is performed only for companies Parmalat and Vigor (4th and 15th in the rankings, respectively), covering the period 1997 to 2006. The reason for the choice of these two companies is the unavailability of financial statements covering all the years of the period under analysis, for the other companies.

\subsubsection{Parmalat}

Parmalat in 2002, in order to meet the operational restructuring, industrial, functional plans and cost reduction sold its stake of $99.99 \%$ of the capital stock of subsidiary Companhia Brasileira de Laticínios - CBL. In addition, during the same year, it sold units and other assets related to the production area. The actions undertaken by the managers at the time did not prevent the company from facing BBR, Braz. Bus. Rev. (Engl. ed., Online), 
financial difficulties since the last quarter of 2003, whose reflection was loss was in 2004 (Bovespa, 2008).

In late November 2003 judicial intervention occurs in the headquarters in Italy, affecting the business of Parmalat Brasil S / A. One of the consequences of judicial intervention that occurred in headquarters was that it compromised the flow of financial resources, disabling it to fulfill commitments and forcing it to seek bankruptcy prevention. The Judicial Recovery Plan of Parmalat Brasil S / A was approved in AGC - General Meeting of Creditors on December 22, 2005. On April 26, 2006, AGC approved the increase and subscription of capital stock in the amount of R \$ 20.010.000,00, by the controlling company Lácteos do Brasil S.A., which started to retain $98.5 \%$ of the capital stock. Chart 2 shows the indicators prepared based on Fleuriet's, indicating the operational and financial difficulties of Parmalat.

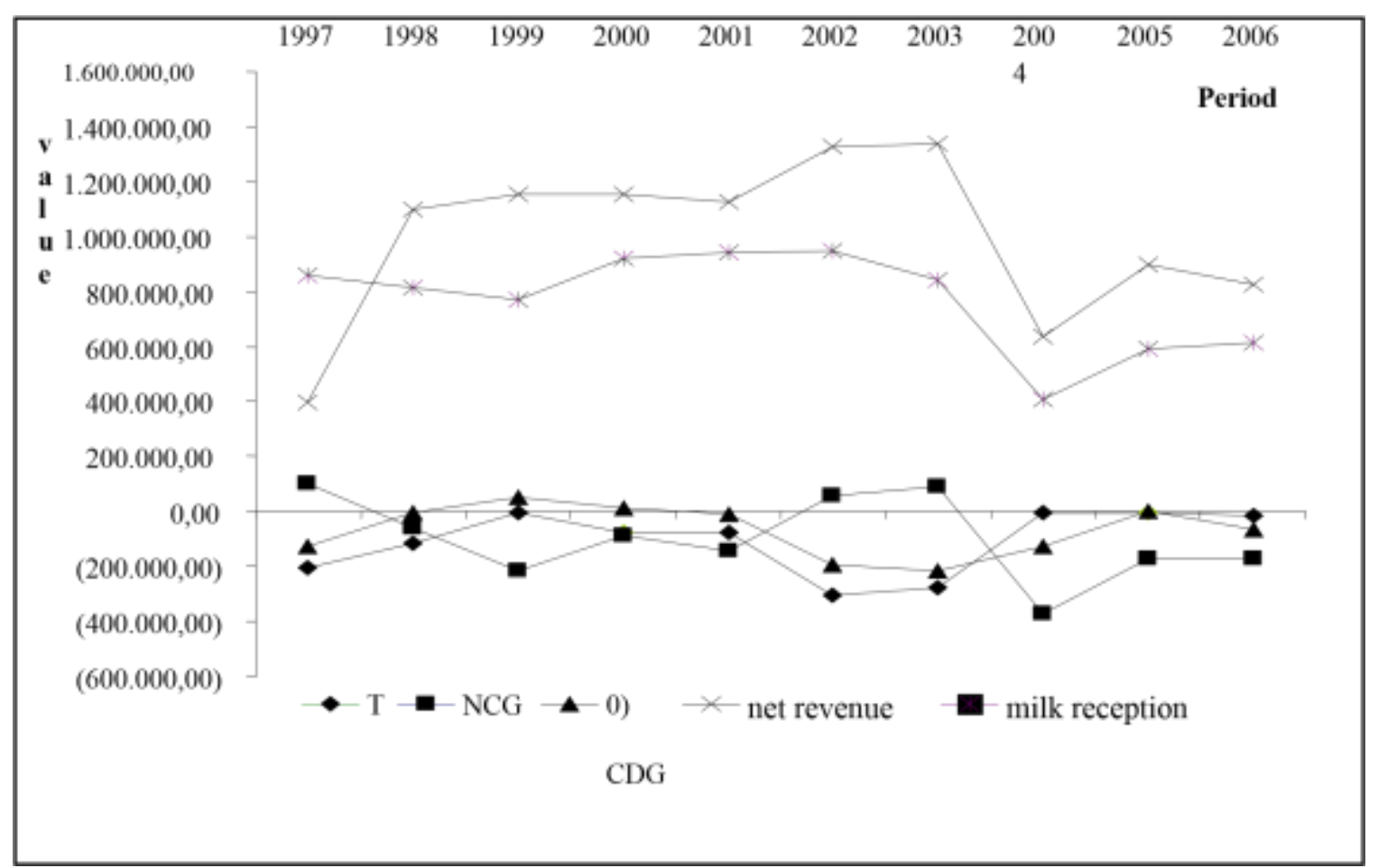

GRÁPH 2 - PARMALAT: PERFORMANCE (1997-2006)

Source: Data organized by the authors based on research

As shown in Chart 2, with respect to developments in real operational and financial variables, the growth in revenues between early 2001 and late 2003, along with the sale of assets, contributed to the improvement of the NCG. Analyzing the economic and financial cycle of Parmalat under the approach proposed by Fleuriet et. BBR, Braz. Bus. Rev. (Engl. ed., Online), 
al. (1978), we observed that the cash balance (T), has a historic deficit from 1997 to 2003, balancing itself as of 2004. In the period under analysis, indicators NCG and CDG, which are economic-financial concepts, reflecting the changes occurred in the economic and operational environment (FLEURIET et al., 1978), in which Parmalat operated. The reversal in signal of the NCG recorded in 2002 and 2003 is due to the sales of assets as proposed in the restructuring plans and not only to improvements in its operational performance and the consequent expected reflections in the economicfinancial indicators. Position T in 2004 and in subsequent years suggests an improvement in the economic and financial situation of the company. Considering $\mathrm{T}=$ CDG - NCG, we observe in Chart 2 that in the year 2004 and onwards, the CDG is at levels slightly positive and therefore a source of funds that finance the NCG.

Resulting from the restructuring process of the company undertaken in 2002 and the Judicial Recovery Plan in 2005, a new organizational and operational structure was set up. One indicator that suggests improvements in efficiency, effectiveness and operational performance of Parmalat, is the volume of milk received. The volume of milk received declines slightly in the period 2002 to 2003, is accentuated in 2004 and it recovers in 2005 and 2006. The reduction in the levels of the activities was accompanied by the drop of the income for the period under consideration. Since Parmalat is a major player in the dairy market, when it repositioned itself it brought about changes in the industry structure and, consequently, in its market share. The result of this analysis in the context of ECD suggests that the operational and financial performance has influenced its participation in the market.

The analysis of the results suggests that there is adherence to the proposition of Rocha, Bueno and Pires (2004) regarding the endogenous relation that would explain the bi-directional influence among the variables in the ECD. Therefore, in company Parmalat bas operational and financial performance influenced the changes occurred in market structure. In addition to losses, cash flow problems and the noisy case of the Italian headquarters, there was no flow of resources that enabled the reception of milk at the appropriate volume for continuity and sustainability of the business. The reduction of milk received in natura impacts the volume processed, the production and consequently sales. 


\subsubsection{Vigor}

Company Vigor, Vigor Group's main company, headquartered in the state capital of São Paulo, is a producer of dairy products. Its main products are: yogurt, fermented milk, curd, cheese, butter and dairy drinks. At the time, Vigor had three factories, located in São Paulo (SP), Santo Inácio (PR) and São Gonçalo do Sapucaí (MG). The unit of São Gonçalo do Sapucaí (MG) accounted for $66.2 \%$ of consolidated net revenue of the Group in 2006 (Bovespa, 2008).

At the time, Vigor held approximately $100 \%$ of the voting capital and $80 \%$ of the total capital of Leco, a company operating in the sector of fats, dedicated, mainly to the manufacture of margarine, mayonnaise, vegetable cream, and edible vegetable oils. Leco, headquartered in the state capital of São Paulo, had factories in São Caetano do Sul (SP) and Anápolis (GO). In 2006, its participation in the Vigor Group's consolidated net sales income was 28\% (Bovespa, 2008).

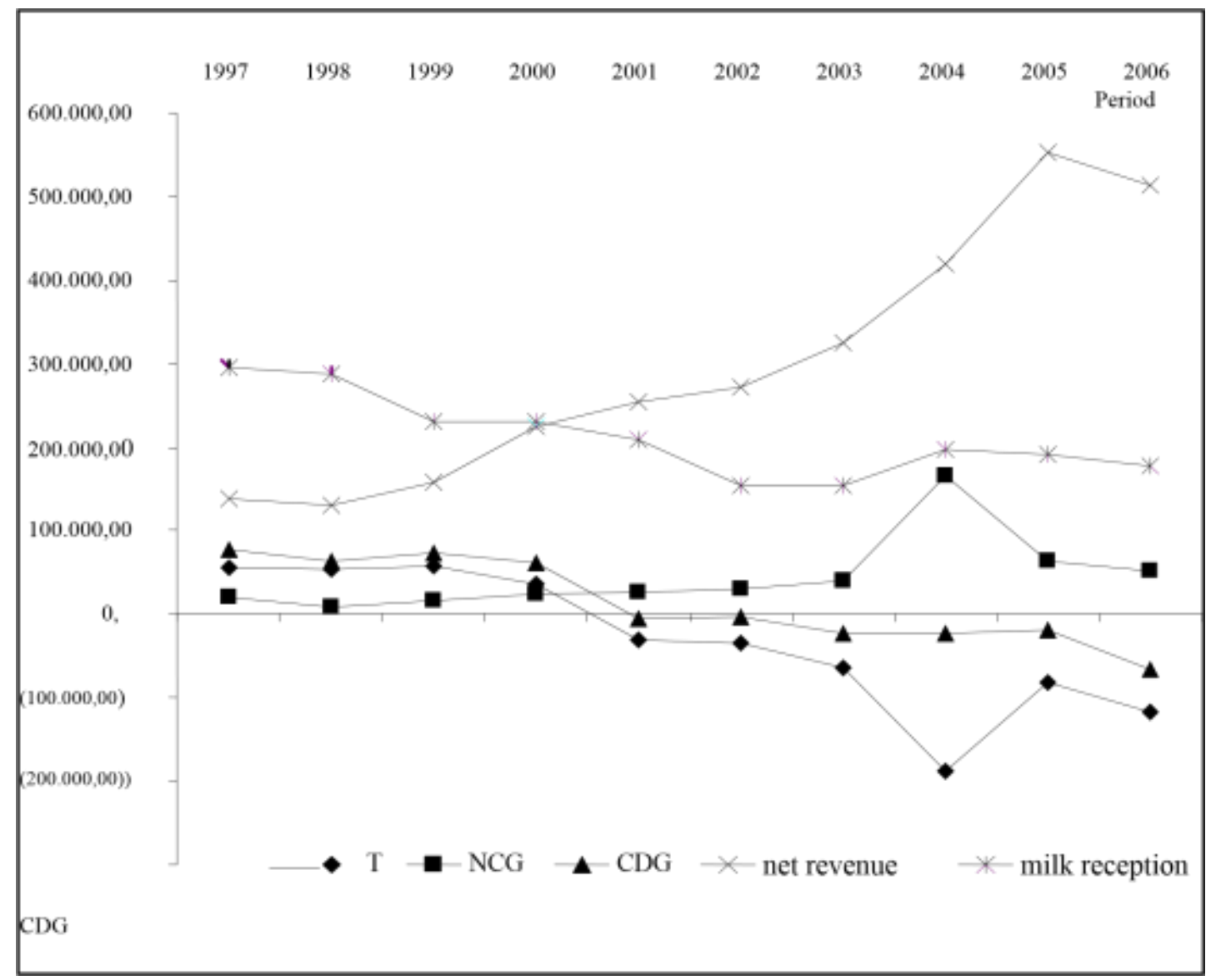

GRÁPH 3 - VIGOR: PERFORMANCE (1997 a 2006)

Source: Data organized by the authors based on research 
The analysis of the indicators listed in Chart 3 shows a reduced level of milk reception, albeit gently, but continuously in the period 1997 to 2006. Net income, in contraposition to the reduction of milk received, kept upstream up to 2005, after which, it is downstream. Operational and financial difficulties, as per indicators T, NCG and CDG have worsened since the year 2000 and in 2006 there are no signs of improvement. From the year 2000 the company had to resort to short-term financial resources (negative cash), to fund investments in working capital, growing, and permanent investments, also with a growth trend from the year 2005.

The analysis of the results suggests that the adverse operational and financial performance, coupled with the reduction of incoming milk, influenced - in the period under review - the position of Vigor in the market structure of the industry. While remaining among the eight companies CR (8) in 2006, it lost two places, from the 6th to the 8th position.

\subsection{Considerations on the research findings.}

Results of studies of Donsimini et.al. (1984) and Rocha, Bueno and Pires (2004) on the performance and concentration of the industries based on the ECD paradigm, suggest that the relations of influence are bi-directional and therefore an endogenous relationship among the variables of the ECD. In the case of the companies surveyed in this study, the results suggest the influence of performance (operational and financial) in the structuring of the sector.

The analysis of operational and financial aspects of corporate performance was made based on the Fleuriet's model (1978). Company Parmalat, among the companies surveyed, went through serious financial difficulties, made worse by administrative issues, in addition to the creditors' agreement of the headquarters, in Italy. In the same period that the financial statements showed a loss, the company received less milk in nature and, therefore, reduced the production of derivatives. As the volume of milk received was the basis for calculating the concentration ratio, the industry structure was modified specifically in the scope of CR (4). Therefore, as of 2004, reorganization of the players' position is begun, due to the incorporation of the market share not met by Parmalat by other companies.

Company Vigor, despite growing revenues in the period 1997 to 2005 did not present an operational and financial situation that could be considered satisfactory. The 
operational and financial indicators calculated according to the Fleuriet's model (1978), indicate that the company raised funds from third-parties to finance permanent investments. The investments, according to Table 1, occur in the years 2005 and 2006, after a sharp reduction in the uptake of milk in 2002 and 2003, resulting in a drop of two positions in the CR (8). The reduction in milk uptake, started in 1998, presents a slight recovery in 2003-2004 and again a gentle drop in the following years, impacts the operational and financial indicators, resulting in a new market position. In this case, the results suggest that there was a unidirectional influence in which the structure influenced the company's performance to the extent that other companies encompassed part of its milk share uptake. In the dairy industry, the volume of milk received is an indicator linked to production, showing if the company is operating at a level of activity appropriate to the size of its plan or not. In the case of Vigor, reducing the volume of milk received, and therefore operating below its optimum capacity reduced self-financing, forcing it to resort to the market to raise funds from third parties preferably in the long term - to finance its investments in permanent assets.

\section{FINAL CONSIDERATIONS}

The Brazilian economy from the beginning of the 90s has undergone profound changes in the institutional framework. The deregulation of many economic activities in conjunction with a policy of economic opening, caused changes in the ratio of concentration of various economic sectors and therefore in the structure. The dairy industry has experienced moments of intense changes. Deregulation and economic opening in a period that some traditional enterprises faced financial and administrative crises contributed to a new order, in which some players lost their traditional space, influence and market positions. The results of this study - considering the period under examination - reveal that in the dairy industry, concentration decreased. Moreover, operating in a competitive environment has forced companies to become more efficient, resulting in increased productivity and decreased the volume of milk imported into the country in recent years, and thus contributing to the improvement of the Brazilian trade balance.

We understand that the academic impact of this research lies in the interaction with other areas of knowledge, especially the accounting, by using the Fleuriet's (1978) in specifying the operational and financial variables rather than (only), for 
example, profit and billing that usually are used. The use of operational and financial indicators allows for a more effective follow-up of the market repercussions in the health of the business and understanding how it influences their position in the market structure. For practitioners, the impact stems from the disclosure of how intertwined the financial and operational issues are with the concentration of market based on model ECD. The broad understanding of these issues will enable managers to antitrust agencies to monitor practices that endanger firms with lower economies of scale and / or bargaining power with other economic agents. Thus, it will be avoiding concentration in a few companies and the harmful effects of collusive behavior on the part of the managers responsible.

Among the limitations of this research, an important one is the lack of economic and financial data of companies operating in this area, since the legal constitutions of many participants do not require the provision of their balance sheets. One should strive to achieve the financial statements of these companies for a more thorough study.

Finally, suggestions for future research, in addition to seek financial statements of other companies, is also to extend the time horizon of the study. In this case, one would be able to analyze the impact of operational and financial performance of companies in the market structure under the ECD paradigm, separating the periods into before and after the crisis.

\section{REFERENCES}

BYRNS, R.T.; STONE, G.W. Microeconomia. São Paulo: Makron Books, 1996.

BRAGA, Roberto. Análise avançada do capital de giro. Caderno de Estudos, São Paulo, 1991.

BRANDÃO, A.S.P. Aspectos econômicos e institucionais da produção de leite no

Brasil. In: Restrições técnicas, econômicas e institucionais ao desenvolvimento da cadeia produtiva do leite no Brasil. Juiz de Fora, EMBRAPA-CNPGL, 1999.

BOVESPA. Relação com investidores. Disponível em: <www.bovespa.com.br> . Acesso em 15 fev 2008.

CARLTON, B.; PERLOFF J. Modern industrial organization. 2 ed. New York: Harper Collins College Publishers, 1994.

CARVALHO, V. R. F. Indústria de laticínios no Rio Grande do Sul: um movimento após o movimento de fusões e aquisições. In: $1^{\circ}$ Encontro de Economia Gaúcha. Governo do Estado do Rio Grande do Sul: Fundação de Economia e Estatística, 2002. 
COSTA, C. N. et. al.. Variabilidade Genética das produções de leite, gordura e proteína da primeira lactação de vacas da raça holandesa. In: V Simpósio da

Sociedade Brasileira de Melhoramento Animal. Pirassununga, SP, 08 e 09 de julho de 2004. Disponível em:

<http://www.sbmaonline.org.br/anais/v/trabalhos/bovinoleite/0.16.pdf >. Acesso em: 16 jan 2008.

CUNHA, J.C. Reestruturação agroindustrial e mudanças institucionais na rede láctea paulista. São Carlos, 2005, 199p. Dissertação (mestrado)-Universidade Federal de São Carlos.

DONSIMONI, M. P.; GEROSKI, P.; JACQUEMIN, A. Concentration Indices and Market Power: Two Views. The Journal of Industrial Economics 32(4), 419- 434, 1984.

ECONOMÁTICA. Banco de dados. 2008.

FIGUEIRA, S. R.; BELIK, W. Transformações no Elo Industrial da Cadeia Produtiva do Leite. In: Revista Cadernos de Debate. vol. III. UNICAMP, 1999.

FILHO, P. J. M; MATTE, V. A. Mudanças institucionais e reestruturação na Indústria brasileira de laticínios (1990-2000). In: Revista Economia e Desenvolvimento, nº 18 , 2006.

FLEURIET, Michel; KEHDY, Ricardo; BLANC, Georges. A dinâmica financeira das empresas brasileiras. Belo Horizonte: Fundação Dom Cabral, 1978.

FLEURIET, Michel; BRASIL, Haroldo Vinagre. Planejamento financeiro das pequenas e médias empresas: um modelo integrado. 2. ed. Belo Horizonte: Fundação Dom Cabral, 1979.

GIL, Antonio Carlos. Métodos e técnicas de pesquisa social. - 5. ed. - São Paulo: Atlas, 1999.

GOMES, A. T. et. al.. O Agronegócio do leite no Brasil. Juiz de Fora: EMBRAPA Gado de Leite, 2001.

HOFFMANN, R. Estatística para economistas. São Paulo: Pioneira, 1991.

JANK, M. S; GALAN, V. B. Competitividade do sistema agroindustrial do leite. São Paulo: PENSA/USP, 1998.

JANK, M.S; FARINA, E.M.M.Q; GALAN, V.B. O Agribusiness do leite no Brasil. São Paulo: Milkbizz, 1999.

RESENDE, Marcelo; BOFF, Hugo. Concentração industrial, capítulo 4. pp 73-90, in Kupfer, David e Hasenclever, Lia [organizadores]. Economia industrial: fundamentos teóricos e práticas no brasil. - Rio de Janeiro: Elsevier, 2002.. 
KON, A. Economia industrial. São Paulo: Nobel, 1999.

LAKATOS, Eva Maria; MARCONI, Marina de Andrade. Metodologia científica: ciência e conhecimento científico, métodos científicos, teoria, hipóteses e variáveis. 2. ed. São Paulo: Atlas, 1991.

MELHORES e MAIORES. Anuário da revista exame. Disponível em:<www.exame.abril.com.br/serviços/melhoresemaiores/> . Acesso em: 13 jan. 2008

MORAES, M.A.F.D. A Indústria de madeira preservada no Brasil: um estudo de sua organização industrial. Piracicaba, 1996, 154p. Dissertação (mestrado)-Escola Superior de Agricultura “Luiz de Queiroz", Universidade de São Paulo.

PONCHIO, Leandro Augusto; GOMES, Alexandre L.; PAZ, Erica. Perspectivas de consumo de leite no Brasil. CEPEA/ESALQ/USP, 2005. Disponível em: < http://www.cepea.esalq.usp.br/pdf/artigo_leite_04.pdf>. Acesso em: 02 jan 2008.

RICHARDSON, Roberto J. Pesquisa social: métodos e técnicas. São Paulo: Atlas, 1999.

ROCHA, Frederico; BUENO, Salua; PIRES, Luiza Nassif. Dinâmica da concentração de mercado na indústria brasileira, 1996-2003.

CEPEA/ESALQ/USP, 2004. Disponível em: < http://www.cepea.esalq.usp.br/pdf/artigo_leite_04.pdf〉. Acesso em: 02 jan 2008.

SANTOS, G. T., VILELA, D. Produção leiteira: analisando o passado, entendendo o presente e planejando o futuro. In: Anais da XXXVII Reunião Anual da Sociedade Brasileira de Zootecnia. Viçosa, MG, jul. 2000.

SCHERER, F. M.; ROSS, D. Industrial market structure and economic performance. 3.ed. Boston: Hougthton M. Company, 1990.

SCHMIDT, C.A.J., LIMA, M.A. Índices de concentração. Rio de Janeiro: MF/Secretaria de Acompanhamento Econômico - SEAE, 2002.

SCHMALENSEE, R. Inter-industry studies of structure and performance. In Schmalensee, R. e Willig, R. Handbook of Industrial Organization. North Holland, Amsterdam, 1989.

TEIXEIRA, N.M. Padronização da produção de leite para duas ordenhas na raça Holandesa. Juiz de Fora: EMBRAPA-CNPGL, 1998. 
ANNEX I - BRAZIL: 15 LARGEST DAIRY INDUSTRIES ACCORDING TO MILK RECEPTION - 1997 to 2006

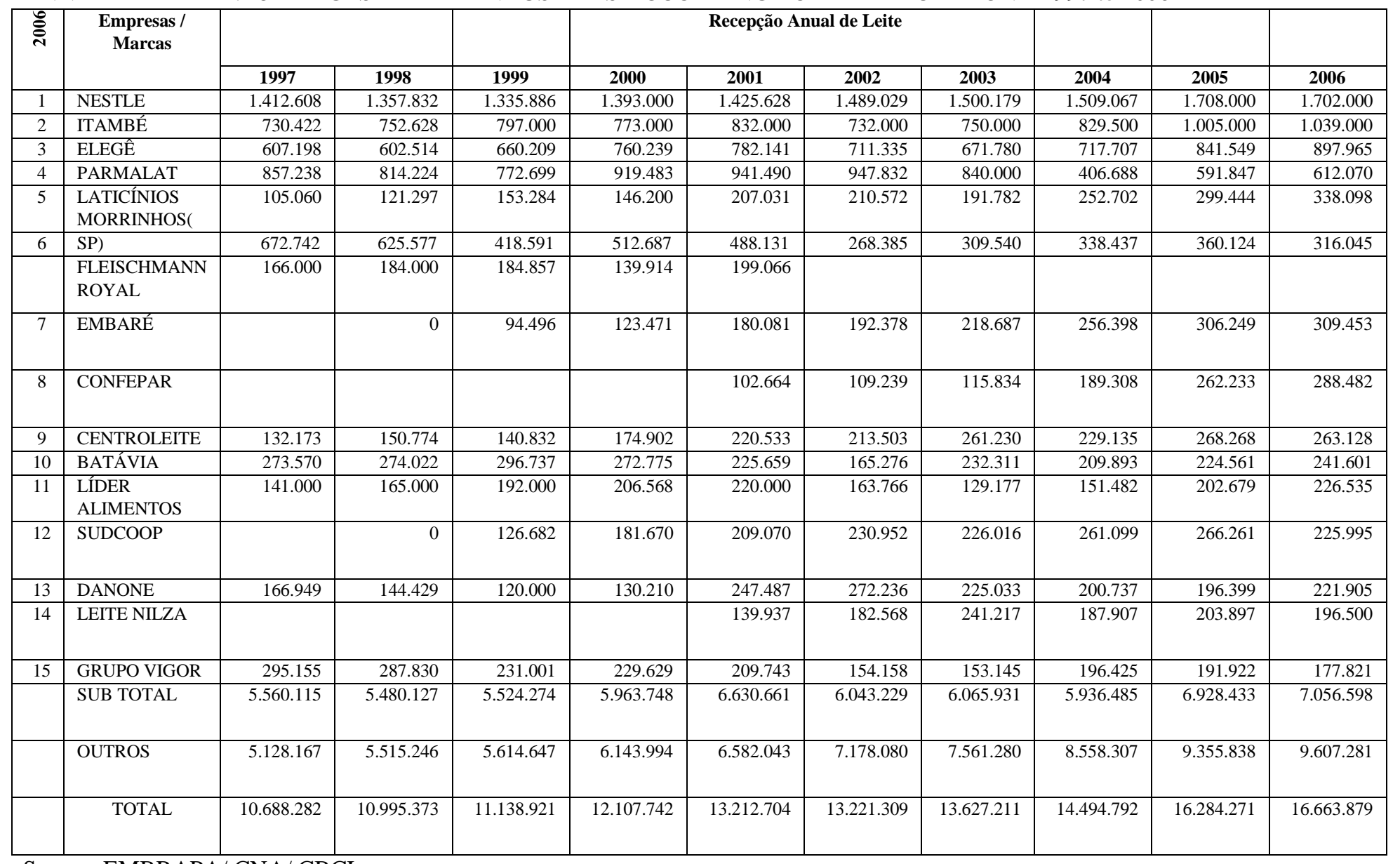

Source: EMBRAPA/ CNA/ CBCL 